IJOLTL, Vol. 2, No. 2, May 2017

p ISSN: 2502 2326; e -ISSN: 2502 8278

Http://ijolt1.pusatbahasa.or.id; Email: ijolt1@gmail.com

Center of Language and Culture Studies, Surakarta, Indonesia

Adi, Titian Wiruma \& Sumarlin, Evi. 2017. Female Flirting in Miss Pettigrew Movie. IJOLTL (2017), 2(2): 83 102.

\title{
FEMALE FLIRTING IN MISS PETTIGREW MOVIE
}

\author{
Wiruma Titian Adi \& Evi Sumarlin \\ ABA BSI Jakarta \\ wiruma.wmt@bsi.ac.id
}

\begin{abstract}
The aims of this research are to identify flirting used in the movie and the message behind the flirting and their effects. Relying upon qualitative method, data were analyzed using constant comparison methods. Steps of collections included: watching the movie, reading books which contain of flirting of speaking, putting the theory of flirting into a movie to select the movie that can be explored by the theory, and identifying the type of flirting speaking based on the movie. The female flirting constituted real data about the elements of women language, and interpretations meaning from the effect of female flirting in speaking. The results of this research indicated that female flirting has some styles of language that can be seen from the element of women language. Evidently, types of meaning which can help to know the interpretations and the effects of female flirting appeared in the movie.
\end{abstract}

Keywords: Miss Pettigrew, Female Flirting, Meaning.

\section{Received: 10 January, 2017; Accepted: 4 April 2017}

\section{INTRODUCTION}

A language is a syntactically organized system of signals, such as voice sounds, intonations or pitch, gestures, or written symbols, which enable communicate thoughts or feelings with other around them. Therefore, learning language has purposed to understand a language as it is spoken, then speaking, and reading before writing it. Meanwhile, people can learn a lot of language for communication among nations between them.

Thus, languages, like cultures, are used by many people on the earth to communicate. The necessity for doing communication makes people try to get contact with others in different languages. This condition attracts people to learn more about languages to satisfy their curiosity. This is the most massive and inclusive art people know an outstanding and anonymous work of unconscious generation. As an inclusive art, language has its own part to be tended and concerned in man life part.

Besides languages have a great existence in a life part; language also has another part to be especially concerned in the words of sentence. When someone talks about language, it can be separated from the learning of its study, and linguistic is one of the interesting studies. Linguistics is the scientific study of language which has a certain respect to natural and conventional signs, called words. 
IJOLTL, Vol. 2, No. 2, May 2017

p ISSN: 2502 2326; e -ISSN: 2502 8278

Http://ijolt1.pusatbahasa.or.id; Email: ijolt1@gmail.com

Center of Language and Culture Studies, Surakarta, Indonesia

Adi, Titian Wiruma \& Sumarlin, Evi. 2017. Female Flirting in Miss Pettigrew Movie. IJOLTL (2017), 2(2): 83 102.

Linguists studying several languages have found evidence of 'sex exclusive' language forms, that is, cases in which an obligatory grammatical distinction is made between female and male speakers.

Those signs or words in language are used by someone to deliver a message in communication. To deliver the message someone could use by two ways, verbal or nonverbal communication. Verbal language is when someone communicates their message verbally to whoever is receiving the message or direct speech. The second, non-verbal communication is usually understood as the process of communication through sending and receiving wordless messages. Such messages can be communicated through body language; gesture or posture; facial expression and eye contact; object communication such as clothing or hairstyles.

The verbal and non-verbal communication used when people want to attract someone else in flirting. Flirting has always been a fun way to connect with others so it is no wonder that in the twenty-first century flirting is making a triumphant return. Every day you meet people, some you know, some you don't, some you'd like to know and some you won't. The quality of your life is often determined by the quality of these interactions. Flirting is a wonderful thing, bringing energy to your daily interactions and improving your life; whether by getting you a better table at a restaurant, a smile from a stranger or meeting your soul mate.

Flirting is like dancing. One person leads while the other has the choice to follow or not. If they choose to use flirting, there is a rhythmic flow of energy where both people benefit.

The writers took Female Flirting in Miss Pettigrew Movie for their title, because this movie showed the flirting spoken in many ways which use the theory of flirting. The writers tried to understand about the requirements which are given to analyze the theory of language and sex. In this opportunity, the writers also would like to discover about female flirting language in Miss Pettigrew movie.

The scope of this research is the female flirting in Miss Pettigrew movie. The limitation is the flirting speaking or language use of Delysia Lafosse, one of the major characters in this movie, is flirted to 3 guys (Nicholas, Philip, and Michael) and the interpretation of the language meaning she used.

Flirting according to Clark (2009:117), "being positive in flirting speaking is needed. Language makes a big difference to how you view something. Choose your words carefully and you're more interesting to the people you want to impress. Being positive is absolutely crucial."

It means, talking positively helps you maintain an open posture, an attractive tone of voice, and an animated and attractive facial expression. Negative language will close your posture - you may find your arms and/or legs start crossing - and the quality of your voice will suffer. You start to close the conversation down. Positive language has a huge effect on the people you are speaking to. They feel energized around you and want to further the conversation. 
IJOLTL, Vol. 2, No. 2, May 2017

p ISSN: 2502 2326; e -ISSN: 2502 8278

Http://ijolt1.pusatbahasa.or.id; Email: ijolt1@gmail.com

Center of Language and Culture Studies, Surakarta, Indonesia

Adi, Titian Wiruma \& Sumarlin, Evi. 2017. Female Flirting in Miss Pettigrew Movie. IJOLTL (2017), 2(2): 83 102.

The analyzing the spoken of flirting through movie need some certain questions to build the core of the discovered problem. These questions are to guide the writersto analyze and to identify the used of flirting spoken in the movie. This study therefore is focused to see:

1. The identifications of women language in flirting.

2. The interpretations of female flirting.

3. The effects are appeared of female flirting.

In the next explanation, there is an identification of women language, it is supported by theory of Lakoff. It helped to identify the sentences of flirting in Miss Pettigrew movie. The interpretation and the effects of female flirting are supported by theory of Leech. It explained the meaning of word.

\section{METHOD}

The writer uses descriptive qualitative method in working out the data analysis, and the writer uses library research to get and collect the ground theories of flirting speaking for referents.

"By the term qualitative research we mean any kind of research that produces finding not arrived at by means of statistic procedures or other means of quantifications", was according to Corbin (1998:17). Some of the data may be quantified as will census data but the analysis itself is a qualitative one.

Basically, there are three major components in qualitative research, such as: the data, which as mentioned can come from various sources; analytic or interpretive procedures that are used to arrive at findings or theories. These procedures include the techniques for conceptualizing data; the last is written and verbal reports. These may be presented in scientific journals or conferences and take the aspects of findings or theory being presented.

From the qualitative method or research that the writer did, steps of the basic components the method itself. First, the writers watched the movie for many times; saw the flirting speaking tendency from Miss Pettigrew movie. After that the writers collected the books which contain of flirting speaking; then the writers tried to identify and analyze every flirting speaking in the movie, including find many references from some sources which involves the topic of this research. For the last step the writers made the conclusion about the type of flirting speaking based on Miss Pettigrew movie.

\section{FINDINGS}

\subsection{Gendered Language}

These are ten elements of the language that women use, as identified by Robin Lakoff in 1975. Of course, not all women use all of this language all of the time, and some may question the whole. It would be also do a duplicate study now and see how much of this has changed since the 1970s, Lakoff (1973:6). Ten elements of the women language are explained by Lakoff (1973:6) as follows. 
IJOLTL, Vol. 2, No. 2, May 2017

p ISSN: 2502 2326; e -ISSN: 2502 8278

Http://ijolt1.pusatbahasa.or.id; Email: ijolt1@gmail.com

Center of Language and Culture Studies, Surakarta, Indonesia

Adi, Titian Wiruma \& Sumarlin, Evi. 2017. Female Flirting in Miss Pettigrew Movie. IJOLTL (2017), 2(2): 83 102.

\section{Hedging}

Hedges are a study in meaning criteria and the logic of Fuzzy Concepts. Lakoff defines 'hedges' (from the point of view of language philosophy) as words whose function is to make meaning fuzzier or less fuzzy. Hedging provides a way out, should disagreement occur, qualifying statements with non-absolute language, using phrases, such as 'sort of', 'I guess', etc.

Well, I sort of looked at him, and then he kind of looked back. Then I guess I kept looking.

\section{Politeness}

Politeness is taken to more extreme forms, either putting the speaker in an inferior position or seeking to be thoughtful and non-threatening towards the other person. Politeness is best expressed as the practical application of good manners or etiquette. It is a culturally defined phenomenon, and therefore what is considered polite in one culture can sometimes be quite rude or simply eccentric in another cultural context.

- Do excuse me, but I really appreciate it if you could take a little time to help me.

- Would you mind...?

\section{Tag Questions}

Tag question is a constituent that is added after a statement in order to request confirmation or disconfirmation of the statement from the addressee. Often it expresses the bias of the speaker toward one answer. Tag questions added to the end of a statement do not change the statement, although they do seek agreement.

- You would do that, wouldn't you?

- You're going to dinner, aren't you?

\section{Emotional Emphasis / Speak in Italics}

The emotional content of sentences is increased through the use of intonation that emphasizes and exaggerates emotional, use tone to emphasis certain words, or intonational emphasis equal to underlining words.

You are so very kind. I really want you to know I am so grateful.

\section{Empty Adjectives}

Adjectives are applied to soften and add friendly elements to the sentence, although they are doing not add any particularly meaningful content.

- What a charming and sweet young man you are!

- Gorgeous

\section{Correct Grammar and Pronunciation}

Care is taken to be correct with language and speech. Colloquialisms and slang are used far less than men. Use a prestige grammar and clear articulation, correct 
IJOLTL, Vol. 2, No. 2, May 2017

p ISSN: 2502 2326; e -ISSN: 2502 8278

Http://ijolt1.pusatbahasa.or.id; Email: ijolt1@gmail.com

Center of Language and Culture Studies, Surakarta, Indonesia

Adi, Titian Wiruma \& Sumarlin, Evi. 2017. Female Flirting in Miss Pettigrew Movie. IJOLTL (2017), 2(2): 83 102.

grammar and pronunciation (hypercorrection) is sometimes found among speakers of less prestigious language varieties who produce forms associated with high-prestige varieties, even in situations where speakers of those varieties would not.

I would be very appreciative if you could show me the way.

\section{Lack of Humor}

Humor is not used very much and jokes are very seldom told. Women do not tell jokes well and often do not understand the punch line of jokes, speak less frequently.

Poor at telling jokes.

\section{Direct Quotations}

A direct quotation is a report of the exact words used in a discourse. The words that people said are often quoted, even quoting people who quote other people. Men paraphrase more often.

- Then she said that he said, "I won't do it." So I said, "Why not?"

- He said, "I am a fool."

\section{Extended Vocabulary}

Rather than simple language, vocabulary is extended to use descriptive language. Thus, for example a precise language is used to describe colors. Women use more words for things like colors, men for sports.

The walls should be cerise, with a royal blue tracer.

10. Declarations with Interrogative Intonation

Statements are made, but using the intonation used for questions, rising at the end of the statement. Use question intonation in declarative statements, women make declarative statements into questions by raising the pitch of their voice at the end of a statement, expressing uncertainty.

\section{That sounds like a good thing to do? \\ What school do you attend? Eton College?}

From the statement above, about ten elements of language that women use, it can be found the main area of interest in the work that Lakoff was the most famous for her theories on gender discrimination through language. She was one of the first serious linguists to look into the social implications of the differences in men and women's use of speech. It was shown the variation speech and gender in language will be contributed to women's status.

The woman's language is the topic that the writer wants to analyze. She took some dialogues in Miss Pettigrew movie. She concerns in a female (Dellysia, as a major character) flirting in her spoken, when she flirts with many guys (Nicholas, Philip, and Micheal) from this movie. She wants to know the effect from female flirting that the actress did. 
IJOLTL, Vol. 2, No. 2, May 2017

p ISSN: 2502 2326; e -ISSN: 2502 8278

Http://ijolt1.pusatbahasa.or.id; Email: ijolt1@gmail.com

Center of Language and Culture Studies, Surakarta, Indonesia

Adi, Titian Wiruma \& Sumarlin, Evi. 2017. Female Flirting in Miss Pettigrew Movie. IJOLTL (2017), 2(2): 83 102.

The effect of female flirting means that it can know what the character wants to deliver in flirting of spoken. So it has to know the meaning first before it can describe what the female flirting means. In semantic, it can know some elements of meaning.

Leech (2003:19) stated, there are 7 types of meaning which is related to "semantic competence", they are:

\section{Conceptual meaning}

Conceptual meaning means logical, cognitive, or denotative content. It is based on two structural principles, which are contractiveness and constituent structures (in a scientific way). It is usually derived from definitions we find in dictionaries and the appearance of these lexical items. We give these lexical items features (constituent structures) and eliminate other features which are not present (contractiveness structures).

The conceptual meaning of a language can be studied in terms of contrastive feature, depends on the given lexical field, so that (for example) the meaning of the word woman could be specified as (+human, +adult, -male), as distinct from, man, which could be defined (+ human, +adult, + male), man is incompatible with woman because of the distinct feature which is (male feature)

The second principle, which of structure is the principle by which larger linguistic units are built up out of smaller units, (for example) in this sentence:

$\{[($ All $)($ men $)][($ are $)][($ mortal $)]\}$

\section{Connotative meaning}

Connotative meaning is the communicative value an expression has by virtue of what it refers to, over and above its purely conceptual content. To the large extent, the notion of reference overlaps with conceptual meaning.

There are 3 facts in connotative meaning: First, about the 'real world' experience one associate with an expression when one uses or hears it. Second, connotative meaning is peripheral compared with conceptual meaning is that connotations are relatively unstable: that is, they vary considerably, as we have seen, according to culture, historical period, and the experience individual. Third, is indeterminate and open-ended in a sense in which conceptual meaning is not.

- Smooth fellow $\rightarrow$ slick, cunning, liar

- Dog $\rightarrow$ loyalty

\section{Stylistic meaning}

Stylistic meaning means "What is communicated of the social circumstances of language use". It can help people to recognize the words or pronunciation as being dialect and also to recognize the social relationship between the speaker and listener.

- Fellow $\rightarrow$ informal

- Elegant $\rightarrow$ formal 
IJOLTL, Vol. 2, No. 2, May 2017

p ISSN: 2502 2326; e -ISSN: 2502 8278

Http://ijolt1.pusatbahasa.or.id; Email: ijolt1@gmail.com

Center of Language and Culture Studies, Surakarta, Indonesia

Adi, Titian Wiruma \& Sumarlin, Evi. 2017. Female Flirting in Miss Pettigrew Movie. IJOLTL (2017), 2(2): 83 102.

\section{Affective meaning}

Affective meaning is language use which has affective meaning reflects the personal feelings and emotions of the speaker or the attitude to something which is talked about. e.g. in politeness part

'I'm terribly sorry to interrupt, but I wonder if you would be so kind as to lower your voices a little.'

\section{Reflected meaning}

Reflected meaning is the meaning which arises in case of multiple conceptual meaning, when one sense of a word forms part of our response to another sense. Reflected meaning intrudes through the sheer strength of emotive suggestion is most strikingly illustrated by words which have a taboo meaning. The process of taboo contamination has accounted in the past for the dying out of the non-taboo sense of a word: Bloomfield explained the replacement of cock in its farmyard sense by rooster as due to the influence of the taboo use of the former word, and one wonders if intercourse is now following a similar path. So it is the meaning that arises in cases of multiple conceptual meaning, when one sense of a word forms part of our response to another.

In the church service, the synonymous expression (the comforter), it sounds warm 'comforting' but in the religious context, it means the strengthener or supporter, i.e. sense of the word seems to 'rub off' on another sense.

\section{Collocative meaning}

Collocative meaning refers to "What is communicated through association with words which tend to occur in the environment of another word". This means that a word is associated with another based on the environment of the other word.

For example: pretty and handsome share common ground in meaning "good looking", but may be distinguished by the range of nouns with which they are likely to co- occur or (to use the linguist's term) collocate:

Pretty = girl, boy, women, flower, garden, color, village, etc.

Handsome = boy, man, car, vessel, overcoat, airliner, typewriter, etc.

\section{Thematic meaning}

Thematic meaning means that what is communicated by the way in which a speaker or writer organizes the message, in terms of ordering, focus, and emphasis. It is often felt, that an active sentence such as: (1) has a different meaning from its passive equivalent, and (2)Although in conceptual content they seem to be the same.

Thematic meaning is mainly a matter of choice between alternative grammatical constructive, as in:

A man is waiting in the hall

There is a man waiting in the hall.

The kind and contrast by ordering and emphasis also be contrived by lexical means; by substituting. In other case, it is stress and intonation rather than grammatical construction that highlights information in one part of a sentence. From the explanation 
IJOLTL, Vol. 2, No. 2, May 2017

p ISSN: 2502 2326; e -ISSN: 2502 8278

Http://ijolt1.pusatbahasa.or.id; Email: ijolt1@gmail.com

Center of Language and Culture Studies, Surakarta, Indonesia

Adi, Titian Wiruma \& Sumarlin, Evi. 2017. Female Flirting in Miss Pettigrew Movie. IJOLTL (2017), 2(2): 83 102.

of 7 types of meaning, it will be easy when it was applied in the extensive which embraced it. So people can get communicative value alternative.

\subsection{Flirting}

Many people love to flirt, but the understanding of flirting itself is quite different but as far of the use. Some of them had no conscious understanding about how they flirt, they just did their best. People flirt for a variety of reasons. Flirting can indicate an interest in a deeper personal relationship with other person. To support the statement above here is another understanding of flirting which is also taken in a same explaining about the definition of flirting. "Flirting is fun, playful and energetic. Everyone involved gets to feel good about them. It can be a useful way of getting what you want in a way that makes people happy to give it to you", was according to Bryant and Lewis (2003:4).

Because true flirting is ambiguous, you can always get away with it anywhere. When you say something flirtatiously it is fun, but the same line delivered with a sexual motive can sound sleazy and puts people off. The moment flirting moves from ambiguity to the obvious it crosses the line from flirtation to seduction. Seduction is about power or sex or both. Flirting, a playful energy is about making the other person feel good. Flirting can be preluded to seduction and from time to time you may want to cross the line. When someone does flirt to another they will do the best and always try to make someone love be happy.

According to Fox (2004:1) "Flirting is much more than just a bit of fun. It is a universal and essential aspect of human interaction". Those statement means that flirting is not only a bit of fun; it is a basic instinct and part of human nature feeling. Flirting is fun and entertaining when doing some flirting people feels many kind of feeling, such as: happy, energy, give spirit, nervous, speechless, worry to make someone loved disappointed, etc. In additional great flirting always have a positive attitude and put the other person first, because in great flirting someone will not hurt the loved.

The right flirting attitude makes this game fun and safe, because the flirt notices others and genuinely cares for people. Based on Fox opinion Flirting is playful energy, a compliment, and fun, communicating, ambiguous not obvious and flirting is a game of love. When people really want to have someone loved, they will work hard to get him or her. Flirting is like a game, when you play it in the end you will be a winner and getting the happy ending story or you will lost. So if it is not fun, it is not flirting.

Flirting is only natural that people feel attracted to such people. People will always find themselves flirting whenever they find a pleasant person, therefore, it does not really matter what the venue is. "Flirting is a wide topic which explores the human romantic feeling in depth", is according to Githinji (2010:1). Flirting is essential in life; it is part of the nature of humans and a basic instinct, because that reason flirting also existed in all cultures in some form and this is how relationships are born.

Flirting usually involves speaking and behaving in a way that suggests a mildly greater intimacy than the actual relationship between the parties would justify, though within the rules of social etiquette, which generally disapproves of a direct expression of 
IJOLTL, Vol. 2, No. 2, May 2017

p ISSN: 2502 2326; e -ISSN: 2502 8278

Http://ijolt1.pusatbahasa.or.id; Email: ijolt1@gmail.com

Center of Language and Culture Studies, Surakarta, Indonesia

Adi, Titian Wiruma \& Sumarlin, Evi. 2017. Female Flirting in Miss Pettigrew Movie. IJOLTL (2017), 2(2): 83 102.

sexual interest. This may be accomplished by communicating a sense of playfulness or irony. People flirt for a variety of reasons. Flirting can indicate an interest in a deeper personal relationship with other person. Some people flirt simply for amusement, with no intention of developing any further relationship. This type of flirting sometimes faces disapproval from others, either because it can be misinterpreted as more serious, or it may be viewed as cheating if either person is already in a committed relationship with someone else.

Different from James (2009:1), the writer of articles online, he said that: "Flirting is seduction should be subtle and enjoyable", means that when you flirt someone, you need the tenderness of feeling, do not be too aggressive or you will lose the interest of flirting; if you can do the tenderness you will get the enjoyable of flirting.

"Flirting is nature's solution to the problem every creature faces in the world full of potential mates-how to choose the right one", according to Rodgers (2011:1). As a human being we cannot leave alone, we need a partner. With flirting we can find the right one if we do flirt in a good way.

Different from Clark (2009:18) that "Flirting is viewed as something a bit grubby, sleazy, or for airheads simply because, in addition to making you friends and improving your relationships, it also gets you dates." Without flirting, though, life would be duller, lonelier, and a lot less fun. Flirting is a great life skill that you can break down into logical elements, learn, and apply in all sorts of contexts from work to play. Flirting is important for other reasons, too. A recent study showed those modern living places less value on community and the family unit than in previous generations.

From the quotations above it is clearly seen that the understanding of flirting is the way to find the right one with fun, playful and energetic way. Everyone involved gets to feel good about them. It can be a useful way of getting what you want in a way that makes people happy to give it to you. Flirting can involve verbal communication or direct expression that need vocal tone and intonation when do it. With flirting someone also can get the right one as partner in their life.

\subsection{The Strategy of Flirting}

Do we need to have a strategy to flirt or it is just better to let it happen naturally? Flirting is often spontaneous. People do not need to have a strategy to flirt successfully. Flirting is fun when it just happens because there are no expectations and no definitive outcomes in mind - except to have fun.

On the other hand, if someone really wants to have a clear intention then just flirting, it much better to have a strategy. The most common intention with flirting is to be noticed and that works equally well in love. Great flirting always has a positive attitude, but to get a great flirting people need strategy. Sometimes to do flirting people confuse to use which one the greatest strategy that they should use. In the past, flirting was an action that believed to be performed only by females. Today, knowing how to flirt is usually a two-way process. 
IJOLTL, Vol. 2, No. 2, May 2017

p ISSN: 2502 2326; e -ISSN: 2502 8278

Http://ijolt1.pusatbahasa.or.id; Email: ijolt1@gmail.com

Center of Language and Culture Studies, Surakarta, Indonesia

Adi, Titian Wiruma \& Sumarlin, Evi. 2017. Female Flirting in Miss Pettigrew Movie. IJOLTL (2017), 2(2): 83 102. (2010:1):

Here are the several strategies on how people can flirt according to Brixen

1. Flirting with your eyes

2. Be confident when you ask for her or his name, or when you introduce yourself to them.

3. Try to be near her eventually in terms of proximity

4. Compliment your crush honestly

Those strategies explain that if someone want to flirt, start it with eyes because eyes is one of the easiest flirting gesture that people can do. After flirt by using gesture, try to be confident as you can, and honesty is also important to make the approach. There is a line that should never be crossed. It means that a flirt is needed a great strategy to make it success.

According to Bryant and Lewis (2003:178), "Great flirt strategies when there is something or someone they want, great flirts know why, what, when and how, great flirts know what techniques to use when and where, great flirts put it together with style".

Choosing who to flirt with is a bit like selecting which chocolate you are going to have from an assorted box. Everyone has their favorite; they might prefer the favorite taste one and enjoy the taste sensation.

When flirting has an intended outcome people will want to be very clear on the what, the why, then when, and the how. The 'what' is your goal or intended outcome. The 'why' is motivates to go for the goal. The 'when' is timing, packing the right time, place and situation. The 'how' is about the plan of action and the steps that will take.

Other strategy of flirting according to Clark (2009:46) is friendly flirting, "Friendly flirting consists of smiling, making good eye contact, and showing interest in other people". Telling if someone is just being friendly is relatively straightforward. If they are demonstrating only the common behaviors listed in the preceding paragraph, you can assume that the flirtation is purely friendly. Adopt friendly flirting as your general approach to everyone. This type of flirting prepares your flirting skills for the more advanced flirting techniques when you want to bag a date. And, you never know who is watching you: your friendly behavior could be just the cue they need to have the confidence to approach you.

In addition Clark explained that Flirting with intent, it means when someone's interested in being more than just friends and their behavior changes to indicate the romantic motive behind their actions. This intention is hormone-fueled, and being able to tell when this is happening is useful for either progress a relationship or avoiding leading that person on. As establishing if someone wants more than friendship is useful when you're flirting with intent or are trying to determine whether someone else is flirting with intent with you. People who flirt with intent do more than simply smile, make good eye contact, and show an interest. Watch for these behaviors:

1. Standing close to you

2. Touching you more than they touch other people 
IJOLTL, Vol. 2, No. 2, May 2017

p ISSN: 2502 2326; e -ISSN: 2502 8278

Http://ijolt1.pusatbahasa.or.id; Email: ijolt1@gmail.com

Center of Language and Culture Studies, Surakarta, Indonesia

Adi, Titian Wiruma \& Sumarlin, Evi. 2017. Female Flirting in Miss Pettigrew Movie. IJOLTL (2017), 2(2): 83 102.

3. Preening themselves more than usual, perhaps by fixing their hair or smoothing their clothes, and so on

4. Making longer eye contact with you than with other people

5. Paying more compliments to you than is usual for them

6. Making more of an effort with their appearance when with you, perhaps by choosing more impressive outfits to wear

"When your eyes connect, then you register the first stages of attraction. Once you get into conversation, the eyes will still be the main affecters. One of the best forms of flirting is to use active listening signals", was according to James (2009:174). There is no huge sex display involved but it does begin the ritual of sealing you off from other people and creating a sense of being a couple. The techniques are easy as they're very similar to nonsexual listening signals, with one extra and very important point. Use eyegaze as you listen and combine it with all the nodding.

From those explanations the writer takes a conclusion that in strategic flirting needed:

1. Eyes contact: People make their first contact with another person with their eyes. The eyes let the other person see how interested we are in them and play a vital part in communication.

2. Smile: Ten years ago, nobody cared about the color of your teeth, but now darker teeth are seen as very ageing. Make sure, at the very least, that your teeth are clean by visiting the hygienist every six months, and keep that cleanliness topped up with whitening toothpaste. A bright smile is very youthful. For professionally whitened teeth, avoid using a beautician and go to the dentist for a professional, longer-lasting result.

Knowing the technique is having a clear idea of who you want to flirt with and the result of it. To do this people need to get their self into the right attitude, the right place at the right time, and prepared to send the right signals. The strategic flirting is aware to show the action by using the right non-verbal signals and the right flirtatious language, such as poem, letter, song and many more.

\subsection{The Characteristic of Flirting/Dating or Mating}

Women love to communicate, and you will always find them encouraging their men to do the same. Unfortunately, most men don't realize that a woman's idea of communication means actually listening to what she has to say and understanding her as well as relating to her problems without judging her or providing unwanted advice.

It is no secret-men and women have very different communication styles. Women primarily talk to explore their feelings, while men primarily talk to find solutions. But if you want your relationship to work, you need to learn how to listen to her properly and learn what not to say to your girlfriend.

For women, talking and sharing are bonding experiences which help them build relationships. They learn how and who to trust by communicating and paying attention to the smallest of details. Whenever your partner speaks, listen carefully, make eye 
IJOLTL, Vol. 2, No. 2, May 2017

p ISSN: 2502 2326; e -ISSN: 2502 8278

Http://ijolt1.pusatbahasa.or.id; Email: ijolt1@gmail.com

Center of Language and Culture Studies, Surakarta, Indonesia

Adi, Titian Wiruma \& Sumarlin, Evi. 2017. Female Flirting in Miss Pettigrew Movie. IJOLTL (2017), 2(2): 83 102.

contact and ask questions about her feelings. Tell her you see how the situation could be upsetting, difficult or frustrating to her and encourage her to open up without offering any solutions or trying to change her feelings.

Try not to be sarcastic as doing such will insult her intelligence. Give her your undivided attention and remember, you do not have to agree with your partner, just listen and try to understand. Make sure that you are not watching the game while she is trying to discuss your one-year anniversary together. Most importantly, listen for clues in her speech, e.g., she tells you that there isn't enough sex in the relationship. Translate that as she is really telling you that she wants more of you. Better intimacy is a good thing, right?

When you learn how to properly listen to a woman, she will feel understood, respected and reassured and it will lead to fewer communication problems in the relationship. If you value your relationship, you should listen to her. Otherwise, you run the risk of having her find another man who will!

Men and women are very distinct creatures. While men have a tendency to be straightforward, women are often not so simple. Unlike men, women often use hints and insinuations to steer you in their direction, and when trying to understand what they really mean, you are sometimes better off reading between the lines. The following cheat sheet will help you learn how to listen to your woman and bridge the gap between what she says and what she means.

1. "Fine."

This is the word women use to end an argument when they are right.

2. "Just give me five minutes."

If she is getting dressed, this means 30 minutes.

3. "Where is our relationship going?"

What she means is that she would like for you to suggest the idea of the two of you to graduating to a more serious and exclusive relationship.

4. "Nothing."

This word ALWAYS means something, and you should be on your toes. Arguments that begin with "Nothing" usually end with "Fine."

5. "Go ahead."

This is not permission--it's a dare. Whatever it is, do it at your own risk!

6. "Loud sigh."

This is a non-verbal statement that means she thinks you are an idiot and wonders why she is wasting her time arguing with you about nothing.

7. "That's okay."

This is one of the most dangerous statements a woman can make to a man. It means she wants to think long and hard before deciding how and when you will pay for your mistake.

8. "A guy was flirting with me."

She wants you to know that other men are interested in her and that you should appreciate what you have. 
IJOLTL, Vol. 2, No. 2, May 2017

p ISSN: 2502 2326; e -ISSN: 2502 8278

Http://ijolt1.pusatbahasa.or.id; Email: ijolt1@gmail.com

Center of Language and Culture Studies, Surakarta, Indonesia

Adi, Titian Wiruma \& Sumarlin, Evi. 2017. Female Flirting in Miss Pettigrew Movie. IJOLTL (2017), 2(2): 83 102.

9. "You know me so well."

It means that she's starting to feel the L-word, but she doesn't want to be the first one to say it.

10. "Don't Worry About It, I Got It."

Another dangerous statement, meaning this is something that a she has asked you to do several times, but is now doing it herself since you has neglected it. This will later result in you asking "What's wrong?"

Understanding Flirting Skills the Natural Way. Flirting is an innate talent, and many put the flirting skills to use in situations in their day to day life. If you have an understanding about the other person, there is no requirement from your side to learn flirting skills. The characteristics of flirting resemble it to be like that of courtship. Courtship is the way in which one displays his/her interest in the other one. Flirting has changed its face throughout the course of time. Whether one is seeking for a serious relationship or just for fun the flirting skills are made into use to the most extent. You can let the other know about your interest with flirting. Though there are scientific basis for the art of flirting, there are many techniques that are proven to be effective in most of the situations.

Seducing the man is the basic intention of a woman flirting. To achieve that they are ready put greater efforts. Men consider the confidence factor in women to be attractive." A guy finds greatly interested in a women who flaunts with the best confidence. Also, when men give a compliment to women they prefer her to accept it rather than ignoring it in a subtle manner.

In flirting the most important factor is eye contact. Your eyes should speak volumes about your interest in the other one. Many consider eyes to be the windows to the inner soul. So let the other one learn about your interest with the spark that gleams in your eyes. Signaling or complimenting the other ones appearance or characteristics is also considered to be a good point in flirting. Also, give a gentle touch on the back or shoulder to show that you really care. Doing so woman is appropriate with few, since they shy away from such actions. Yet, a gentle touch will sure ignite the interest in you both and it is worth a try.

The mood swings and the talent that women have make it easier for women to manipulate the fine tricks of flirting. The alluring stares and the laughter in an exaggerated manner is what which speaks about the flirting woman. The words the flirting women choose and the way they carry themselves speaks loads about them. Be attentive and find flirting women with ease.

Being happy is another important aspect to consider in girls flirting. Looking and laughing at your guy will make him feel comfortable in your presence. Try witty comments and brush up your sense of humor. Put playful teasing in to use. Even for his silly jokes laugh wholeheartedly so as to give him a feel that you are listening.

What attract us to a mate? How long have you got? There is a strange irony to the attraction process that humans somehow fail to get, which is that the factors that we use to define an attractive person are often the factors that guarantee someone will be 
IJOLTL, Vol. 2, No. 2, May 2017

p ISSN: 2502 2326; e -ISSN: 2502 8278

Http://ijolt1.pusatbahasa.or.id; Email: ijolt1@gmail.com

Center of Language and Culture Studies, Surakarta, Indonesia

Adi, Titian Wiruma \& Sumarlin, Evi. 2017. Female Flirting in Miss Pettigrew Movie. IJOLTL (2017), 2(2): 83 102.

unlucky rather than lucky when it comes to meeting a mate and sustaining a relationship.

Hundreds of empirical studies have been devoted to sexual and romantic attraction, but most were methodologically limited in that they were based on self-report of preferences for attributes of hypothetical partners, indirect inferences on preferences from traits of existing couples or self-presentations in and responses to lonely hearts advertisements. In recent years, researchers have begun to adopt a new dating research design: In speed-dating, multiple men meet multiple women of similar age for brief encounters one after the other. Relationship effects, where one participant is interacting with only one dating partner, these three different effects are inextricably confounded. In a speed-dating design they can be separated, and actor and partner effects can be estimated quite reliably because behavior is averaged across many dyads. Also, speeddaters get access to a dating partner's address only in the case of matching and thus the frequency of matching is a clearly interpretable measure of immediate dating success that reflects the mutual interest of both dating partners.

According to James (2009:166), "When we see a potential mate we also see echoes from childhood and patterns of behavior, plus the visual signals that our subconscious locks into, and the attraction is made. If we only date people we think our friends would approve of we're likely to make some very poor long-term choices". Body movement is one of the great creators of sexual and romantic attraction. We're attracted to people for many complex psychological reasons, not just because they look like a Barbie or Ken doll and our friends would approve. Your sexual programming is something even you would be hard-pressed to understand, which is why our life mate is rarely someone who could be described as universally attractive.

"Starting a flirtation with a potential date is different to flirting with friends", was according to Clark (2009:50). You have to start with a much stronger approach because you get less opportunity to form a first impression with a potential date than with a friend, and you need to make your intentions absolutely clear.

\section{DISCUSSION}

The findings which have been collected by capturing them from the movie Miss Pettigrew, taken from the dialogues of the major female characters, DelysiaLafosse, and the guys (Three men who have relationship with Delysia, Nicholas, Philip, and Micheal). Each every chapter was played in this movie for over those one and a half hours. After the movie chapters have been collected there would be some analysis for each dialogue which has been taken.

Findings are about collecting the dialogues which have to be analyzed. There are some chapters that the writer captured. And each chapter the write would take a dialogue when Delysia flirt to some guys. From the dialogues which have taken, the writer would give some information regarding the condition of the dialogues which are taken, the place, the time, the situation, etc. 

IJOLTL (2017), 2(2): 83 102.

The analysis of the findings is to find out the intended meaning interpreted Flirting that the major character did. The dialogues will be examined related to the female flirting, women's language that is used by the dialogues. So here are the findings and the analysis of the captured dialogues in movie of "Miss Pettigrew".

\begin{tabular}{l|l}
\hline \multicolumn{2}{c}{ Part 1: at Delysia's house - 00:07:44 } \\
\hline Description & $\begin{array}{l}\text { Delysia was got up to Philip (a theatre producer), "Phil! It's time to } \\
\text { wake up, darling!" }\end{array}$ \\
\hline
\end{tabular}

This scene was played at 00:07:44. Delysia's house when Guinevere just arrived. Delysia has another schedule to meet another guy at her house. She called Philip from the upstairs, "Phil! It's time to wake up, darling!" It is clearly this one of hedging by Lakoff, because this is the qualifying statement and using phrases. She said that she wants Phil can get up fast, because she has to prepare for another appointment. This is one of thematic meaning; the message is organized in terms of order and emphasis. It refers to the situation in the morning, when Delysia stated the time. The effect of this flirting is Philip felt happy, because there was somebody takes care with him.

\begin{tabular}{l}
\hline Part 2: at Delysia's house - 00:10:10 \\
\hline Description \\
At 00:10:10 in Delysia's house, she got a phone from someone. With smile and \\
show her happiness, she called him, "Darling!". It is one of empty adjectives, because \\
the statement is not adding any particularly meaningful content. From the meaning, it \\
showed stylistic meaning, because the words as to recognize relationship between the \\
speaker and listener. The using of word "Darling" according to Merriam-Webster (m- \\
w.com), "the origin of Darling is Middle English darling, from Old English déorling, \\
from déore dear. First Known Use: before 12th century."
\end{tabular}

\begin{tabular}{l|l}
\hline \multicolumn{2}{c}{ Part 3: at Delysia's bedroom - 00:12:57 } \\
\hline Description & Delysia kissed Philip, and said "Baby, baby, I'd love to, but I can't." \\
\hline
\end{tabular}

Playing at Delysia's bedroom in 00:12:57, when Philip take Delysia on the bed and ask her to do have fun. Delysia refused and said, "Baby, baby, I'd love to, but I can't." this is one of politeness, because her expressing with non-threatening towards to Phil. From her statement to Phil, that is one of affective meaning, because Delysia reflects her personal feelings to something which is talked about. She showed her feeling to refuse Philip's request. The effect is Phil felt a little disappointed. 
IJOLTL, Vol. 2, No. 2, May 2017

p ISSN: 2502 2326; e -ISSN: 2502 8278

Http://ijolt1.pusatbahasa.or.id; Email: ijolt1@gmail.com

Center of Language and Culture Studies, Surakarta, Indonesia

Adi, Titian Wiruma \& Sumarlin, Evi. 2017. Female Flirting in Miss Pettigrew Movie. IJOLTL (2017), 2(2): 83 102.

\begin{tabular}{l|l}
\hline \multicolumn{2}{c}{ Part 4: at Delysia's bedroom - 00:13:08 } \\
\hline Description & Delysia asked Philip's plan, and said "Who are you lunching?"
\end{tabular}

At 00:13:08, still in Delysia's bedroom with Philip. She asked to Philip his plan to lunch. "Who are you lunching?". According to ten elements by Lakoff, it is one of declaration with interrogative intonation because her intonation used for question. There is an emphasis in the end her statement. From the meaning, this is one of conceptual meaning which present denotative content. Delysia asked with whom Philip will be lunched. The effect is Phil was nervous.

\section{Part 5: at Delysia's bedroom - 00:13:14}

Description Delysia asked Philip's plan, and said "But you said the lead was mine. Phil, honey, you promised."

This scene played in the same place at 00:13:14, when Delysia knew Philip got a meeting with another woman. She got a little bit angry, "But you said the lead was mine. Phil, honey, you promised." This is one of direct quotation, which Delysia quoted from Phil said. Thematic meaning was applied for this part, because the quotation means that what is communicated by the way in which a speaker (Delysia) organizes the message, Delysia gave an emphasis about Philip's promise. The effect of this action, Phil felt guilty.

Part 6: at outside elevator - 00:16:45

\begin{tabular}{l|l} 
Description & Delysia reminded Philip, and said "Don't let any rabbits under your
\end{tabular} fence."

The scene was played at outside elevator, when Delysia reminded Philip to stay away from another woman in his appointment. She said, "Don't let any rabbits under your fence." It is one of direct quotation. This statement means connotative, because the communicative value an expression has by virtue of what it refers to. The effect of this action Phil looks happy.

\section{Part 7: at elevator - 00:16:48}

Description $\mid$ Delysia said goodbye to Phil, "Bye."

The setting of this scene was still in elevator, played at 00:16:18, when Delysia say goodbye to Philip, "Bye." A simple word, but can be interpreted of conceptual meaning, which means denotative meaning, to say goodbye. The effect, Phil is attracted.

Part 8: at Delysia's house - 00:19:22

Description Delysia met Nick and kissed him "It's you!" 

IJOLTL (2017), 2(2): 83 102.

This part of Delysia met Nick at first time, when he just arrived. The place is at Delysia's house, playing at 00:19:22. She looked so happy, then kissed Nick and said, "It's you!". Her statement used question intonation in declarative statements; she made declarative statements into questions by raising the pitch of her voice at the end of a statement, expressing uncertainty. For this statement means connotative meaning because it appeared open-ended statement. The statement can be Delysia was happy with Nick's coming or she didn't want he was there. Although the meaning can be interpreted in some interpretation, the effect is Nick feeling happy of Delysia.

\begin{tabular}{l|l}
\hline \multicolumn{2}{c}{ Part 9: at Delysia's house - 00:19:37 } \\
\hline Description & $\begin{array}{l}\text { Delysia meets Nick, and said "But Nick, I get so lonely when you're } \\
\text { away." }\end{array}$ \\
\hline
\end{tabular}

This part when Delysia got another Nick's attention. She flirt him and said, "But Nick, I get so lonely when you're away." This scene was played at 00:19:37. Her flirting according by Lakoff is included of emotional emphasis / speaks in italic, because the content of sentences is increased through the use of intonation that emphasizes and exaggerates emotional, use tone to emphasis certain words, or intonational emphasis equal to underlining words. Delysia's flirting used affective meaning, because reflects the personal feeling and emotions of the speaker, Delysia. She showed her expression of feeling, if Nick was not be with her, she felt lonely. The effect is Nick feeling happy.

Part 10: at Delysia's house - 00:22:24

Description When Nick thought Delysia was laid, "I'm wounded, Nicholas, I am wounded."

The scene was played at Delysia's house at 00:22:24 when Nick thought that Delysia and Guiniviere were laid. Lying about Delysia's schedule, lying about a cigarette which is found by Nick. In this part her flirting seems like pretending that Delysia regret. She said, "I'm wounded, Nicholas, I am wounded." This is correct grammar and pronunciation based on Lakoff because the statement used correct grammar and pronunciation, and clear articulation. The statement of her regret showed conceptual meaning which means denotative content. The effect in this scene, Nick felt guilty.

\begin{tabular}{l|l}
\hline \multicolumn{1}{c}{ Part 11: at Delysia's house - 00:40:13 } \\
\hline Description & $\begin{array}{l}\text { Delysia sees Micheal at the first time, after long time no see, "It's so } \\
\text { good to see you." }\end{array}$ \\
\hline
\end{tabular}

This part is taken when Delysia and Guiniviere arrived at Delysia's home and saw Micheal was playing a piano. The scene was played at 00:40:13. Delysia expressed her happiness and said, "It's so good to see you." This expression is an emotional emphasis. The expression means affective meaning, because it reflects Delysia's 

IJOLTL (2017), 2(2): 83 102.

feelings and emotions. She was happy when see Micheal was at her house. The effect, Micheal did not show expression, no response.

Part 12: at Delysia's house - 00:40:32

Description Delysia tried to apologize with Micheal, and said "Can you ever forgive me?"

This scene was played at Delysia's house at 00:40:32, when Delysia apologize to Micheal about her fault that she never visited him in a prison. She tries to get his attention first to apologize with him. "Can you ever forgive me?" This part is one of politeness and gives affective meaning, because it reflects of Delysia's feeling and emotion that she is very guilty. The effect is Micheal did not believe with Delysia.

\begin{tabular}{l|l}
\hline \multicolumn{4}{c}{ Part 13: at Delysia's house - 00:41:04 } \\
\hline Description & $\begin{array}{l}\text { Micheal remembered of Delysia said their memory (their } \\
\text { togetherness), "Shake me again No, better not stand too close to the } \\
\text { window." }\end{array}$ \\
\hline
\end{tabular}

This part was played still at Delysia's house at 00:41:04. She flirt Micheal with some declaration that is purposed his passion and can accept her apologized. She said, "Shake me again No, better not stand too close to the window." This statement is about emotional emphasis/speaks in Italic, the content of sentences is increased through the use of intonation that emphasizes and exaggerates emotional, use tone to emphasis certain words, or intonational emphasis equal to underlining words. The meaning is showed in affective meaning.

$$
\text { Part 14: at Bathroom - 00:46:20 }
$$

Description $\quad$ When Delysia give description 3 guys in her life to Miss Pettigrew.

1. "With Nick, I get this magnificent flat and my job at the Peacock."

2. "With Phil, I get the best part on the West End stage on my change to be a star."

3. "With Micheal, I get the best friend that I ever had. He's rather passionate. But Micheal is the one."

This scene was played when Delysia and Miss Pettigrew were at bathroom. Delysia describe of three men in her life. She told of each characteristic and advantages to be with them. The three statements above used of hedging by Lakoff. For Delysia's said about Micheal, she said that "He's rather passionate." It is used emotional emphasis. The meaning that can get from the statements above can be seen by conceptual and affective meaning. Conceptual meaning is for Delysia's description of Philip and Nicholas. The meaning showed denotative, what Delysia explained and thought same with Guenivere. When Delysia described Micheal, there was emotional feeling from her gesture. It is clear showed from her eyes. 
IJOLTL, Vol. 2, No. 2, May 2017

p ISSN: 2502 2326; e -ISSN: 2502 8278

Http://ijolt1.pusatbahasa.or.id; Email: ijolt1@gmail.com

Center of Language and Culture Studies, Surakarta, Indonesia

Adi, Titian Wiruma \& Sumarlin, Evi. 2017. Female Flirting in Miss Pettigrew Movie. IJOLTL (2017), 2(2): 83 102.

Part 15: at Club - 01:16:52

Description $\quad$ Delysia asked Micheal for not go, "Micheal, please wait!"

This part was played at Club at 01:16:52, when Delysia asked Micheal for not going anywhere, only stay with her. She said, "Micheal, please wait!" From the statement, it is clearly to explain direct quotation, which a report of the exact words used in a discourse. The words that she said are often quoted, even quoting a person who quotes other person. The meaning of that statement means conceptual meaning, because the meaning used denotative meaning. Delysia wanted to Micheal for stay with her. The effect is Micheal felt sad.

\section{Part 16: at Club - 01:17:55}

Description Delysia asked Micheal for his offering to marry "is the offer still
open?"

The setting of this scene is at Club. It was played at 01:17:55, when Delysia asked Micheal for his offering to marry. She said, "Is the offer still open?" This part is one of politeness and gives affective meaning, because it reflects of Delysia's feeling and emotion. But the statement, it can be included in connotative meaning, the communicative value an expression has by virtue of what it refers to, over and above its purely conceptual content. The effect is Micheal was confused.

$$
\text { Part 17: at Club - 01:18:06 }
$$

Description Delysia asked Micheal for his definite "will you doggone marry me or will you doggone not?"

Delysia emphasize to Micheal that he will marry her or not. She said, "Will you doggone marry me or will you doggone not?" this one of declaration with interrogative intonation, because statements are made, but using the intonation used for questions, rising at the end of the statement. The meaning of that statement means connotative meaning, the communicative value an expression has by virtue of what it refers to, over and above its purely conceptual content. The effect in this part, Micheal looks happy and unbelievable.

Some evidences above showed that the elements of Lakoff applied in female flirting (major character, Delysia), but almost the whole part used emotional emphasis and politeness to deliver of female flirting in Miss Pettigrew movie. The using of emotional emphasis and politeness are appeared of affective meaning, reflection of feeling and emotion, when the reader wants to know the meaning of female flirting that occurred in this movie.

\section{CONCLUSION}

The thesis is showed seventeen pictures. Each picture has different elements by Lakoff and interpreted in seven type of meaning by Leech. The dialogues and the 
IJOLTL, Vol. 2, No. 2, May 2017

p ISSN: 2502 2326; e -ISSN: 2502 8278

Http://ijolt1.pusatbahasa.or.id; Email: ijolt1@gmail.com

Center of Language and Culture Studies, Surakarta, Indonesia

Adi, Titian Wiruma \& Sumarlin, Evi. 2017. Female Flirting in Miss Pettigrew Movie. IJOLTL (2017), 2(2): 83 102.

pictures from the movie helped the writer in analysis of female flirting. Almost the whole part used emotional emphasis and politeness to deliver of female flirting in Miss Pettigrew movie. The using of emotional emphasis and politeness are appeared of affective meaning, reflection of feeling and emotion

From the analysis of female flirting through the movie of Miss Pettigrew, the writers could give conclusion that the spoken/language are affecting the meaning of natural feeling of the flirting. The pictures which have been chosen and then analyzed are affected by the female flirting. In this part, the writers suggest to all viewers of movie who love watching movie, Miss Pettigrew can be an alternative good movie. In this movie, we can analyze and get moral message.

The writers suggested for readers who want to analyze "flirting strategies", it can be gestures or spoken that can be analyzed, because in this Miss Pettigrew Movie when both of them tried to flirt they used not only gestures but also some spoken flirting. In this paper the writer analyzed flirting spoken especially for female, how a woman attracts some guys loved by verbal language. The writer suggests to the next researcher to analyze the flirting by male. Then try to classify the male spoken flirting, after that try to find the differences between female flirting and male flirting and compare them which one the most effective flirting for someone who will flirt someone loved. There are some differences between western language and eastern language. For further research, It is also can be analyzed to male character in flirting.

\section{REFERENCES}

Brixen, Annita. 2010. Flirting Tips For Guys: Flirting With A Woman You Like. Taken from: www.buzzle.com/articles/definition-flirting.html. (June 19, 2010).

Bryant, Andrew, and Michelle Lia Lewis. 2003. The Street Guide to Flirting. Sydney: Allen \& Unwin.

Clark, Elizabeth. 2009. Flirting for Dummies. West Sussex: John Wiley \& Sons, Ltd.

Corbin, Juliet M. 1998. Basic of Qualitative Research, $2^{\text {nd }}$ Edition. United States of America. Sage Publications.

Fox, Kate. 2004. The Flirting Report. Oxford: The Social Issues Research Center.

Githinji, Francis. 2008. Some Top Flirting Gestures. (October 14, 2008).

Haviland, B. John. 2010. From Dating to Mating and Relating. West Sussex: John Wiley \& Sons, Ltd.

Holmes, Janet. 1992. An Introduction to Sociolinguistics. London: Longman Group.

James, Judi. 2009. The Body Language Rules. Illinois: Sourcebooks, Inc.

Lakoff, Robin. 1973. Language and Women's Place. New York: Cambridge University Press.

Leech, Geoffrey. 2003. Semantics. Yogyakarta. PUSTAKA BELAJAR.

Nalluri, Bharat. 2008. Miss Pettigrew Lives for a Day. New York: Focus Features.

Wardhaugh, Ronald. 2006. An Introduction to Sociolinguistics. Malden: Blackwell Publishing Ltd. 
